Окрім того, запропонована модель відображає динаміку розвитку самовиховної активності студентів-філологів, яку доцільно впроваджувати в навчально-виховний процес педагогічного вишу поетапно, охоплюючи аудиторну та виховну роботу (лекційно-практичні заняття, бесіди, диспути, тренінги, захисти проектів, проведення тематичних вечорів, конкурсів, свят, читацьких та наукових конференцій, реалізація методики самопізнання, самовдосконалення).

\title{
Література
}

1. Жулкевська В. Теоретико-методологічні основи дистанційного навчання / В. Жулкевська // Педагогічна психологія професійної освіти. - 2007. -№ 1. - С. 52-59.

2. Козаков В. Л. Самостоятельная работа студентов и ее информационнометодичекое обеспечение / В. Л. Козаков. - К., 1990. - 246 с.

3. Кредитно-модульна система підвищення якості освіти: [Національний гірничий університет] // Освіта України. - 2005. - №3. - С. 10-14.

4. Кулик Є. Дидактична характеристика процесу самоосвіти / Є. Кулик // Вища освіта України. 2006. -№13. - С. 10-13.

5. Плагов И. М. Пути совершенствования самостоятельной работы студентов в вузе: [учеб. пособ. для ун-тов, вузов, ф-тов повыш. квалиф. препод.] / И. М. Плагов, Т. И. Парубочая. -Челябинск: ЧГТУ, 1991. - 123 с.

6. Саулина О. П. Самостоятельная работа студентов как основа повышения эффективности их будущей профессиональной деятельности / О. П. Саулина, В. Н. Вяткина // Подготовка студентов факультета физической культуры к профессиональной деятельности. - М., 1991. - С. 114-121.

7. Середа I. В. Педагогічна підготовка вчителя в сучасному університеті / I.B. Середа // Неперервна професійна освіта : теорія і практика: [науково-методичний журнал]. - Київ, 2003. - Вип. 2. - С. 27-33.

Стаття надійшла до друку 10.05.2012 p.

УДК 378.091.33'026

С. М. Богомаз-Назарова, кандидат пед. наук, ст. викладач, Кіровоградський ДПУ ім. В. Винниченка

\section{МІЖПРЕДМЕТНІ ЗВ'ЯЗКИ ЯК ДИДАКТИЧНА УМОВА ПІДВИЩЕННЯ ЯКОСТІ ПІДГОТОВКИ МАЙБУТНІХ УЧИТЕЛІВ}

Богомаз-Назарова С. М. Міжпредметні зв'язки як дидактична умова підвищення якості підготовки майбутніх учителів.

У статті здійснено аналіз міжпредметних зв'язків у методичній літературі як важливої передумови підвищення ефективності навчання майбутніх учителів.

Ключові слова: міжпредметні зв'язки, навчальний прочес, майбутні вчителі.

Богомаз-Назарова С. М. Межпредметные связи как дидактическое условие повышения качества подготовки будущих учителей.

В статье сделан анализ межпредметных связей в методической литературе как важной составной при повышении эффективности обучения будущих учителей.

Ключевые слова: межпредметные связи, процесс обучения, будущие учителя.

Bogomaz-Nazarov S. Interdisciplinary communication as a condition for improving the quality of didactic training of future teachers.

In this article the analysis of intersubject connections is examined in methodical literature as important component at an increase efficiency of teaching.

Key words: intersubject connections, educational process, future teachers. 
Постановка проблеми. Усі галузі сучасної науки тісно пов'язані між собою, що створює дидактичні передумови посилення впливу на навчальний процес міжпредметної інтеграції.

У методичній літературі подано різні трактування поняття «інтеграція». Так, Ю. Калягін та О. Алексєєнко визначають його як «процес пристосування й об'єднання розрізнених елементів в єдине ціле за умови їх цільової та функціональної однотипності» [6]. О. Сергєєв, у свою чергу, зазначає, що інтеграція передбачає «встановлення і посилення взаємозв'язків між науками». Науковець наголошує на тому, що інтеграція виникла як основа фундаментальних наук на фоні своєї протилежності - диференціації, яка заклала основи і необхідність інтеграції [10]. Інтеграція є механізмом самоорганізації хаосу знань, - зауважує I. Козловська [8], та визначає цей термін як «процес зближення й зв'язку наук, який діє поряд з процесом диференціації, що становить вищу форму втілення міжпредметних зв'язків на якісно новому рівні навчання» [8]. Інтеграція розглядається С. Колодинським як мета і шлях створення цілісності. Системні цілісні знання науковець трактує як стан, результат, якого можна досягти, здійснюючи інтеграцію. 3 наведених визначень можна встановити значущість інтегративного підходу до навчального процесу, яка виявленняляється в забезпеченні системності та цілісності знань, що зумовлює їх міцність, узагальненість та усвідомлення.

Наразі розглядаються три рівні дидактичної інтеграції, кожний з яких має свою логічну структуру, яка складається 3 базису (визначальної дисципліни); завдання (проблеми базової дисципліни); знаряддя (теоретичного і технічного інструментарію базової та суміжних дисциплін) [6].

Першим рівнем дидактичної інтеграціїє об’єднувальні взаємодії на рівні трансляції, які здійснюються у формі міжпредметних зв'язків. Другий рівень дидактичної інтеграції - це синтез наук, що взаємодіють на основі певної базової дисципліни, так званий «внутрішньодисциплінарний синтез, який об'єднує різні теорії в рамках одного предмета». Таке об'єднання має діалектичний характер, надає можливість ураховувати також диференціацію знань, є методом досягнення єдності наукових знань. Третій рівень дидактичної інтеграції - створення цілісної інтегративної системи, зокрема, інтегративного курсу.

Ми визначаємо застосування міжпредметних зв'язків як перший рівень здійснення дидактичної інтеграції.

Міжпредметні зв'язки як дидактична передумова підвищення наукового рівня знань студентів, чинник, що впливає на оптимізацію навчального процесу, розглядаються науковцями як певна умова, яка впливає на результативність усього навчального процесу. Так, С. Гончаренко зазначає,що основним недоліком, який пов'язаний з формуванням у вищій школі цілісної системи знань у студентів, є роздроблення споріднених дисциплін у навчальних планах вищих навчальних закладів, недостатнє використання міжпредметних зв'язків у навчальному процесі. Це сприяє тому, що синтез інформації, яка пропонується викладачем стихійно 
покладається на студентів, i, якщо вони його здійснюють, то ефект буде значним [3]. Науковець стверджує, що «для продуктивного засвоєння студентом знань і для його інтелектуального розвитку важливе значення має встановлення широких зв'язків як між різними розділами курсу, який вивчається, так і між різними дисциплінами загалом» [3] (внутрішньопредметна і міжпредметна інтеграція). Про це йдеться й у праці Я. Собко та Т. Якимович: «одним 3 основних завдань вищої освіти є систематизація та узагальнення знань, одержаних під час вивчення різних предметів, створення цілісного уявлення щодо предмета навчальної діяльності».

О. Сидоренко вважає, що багатопредметність завдає шкоди формуванню вмінь застосовувати одержані знання для розв'язування практичних завдань, які мають комплексний характер. При цьому спостерігається розосередження схожих тем у різних предметах за місцем у навчальних програмах і за часом їх вивчення.

Ідея вдосконалення навчально-виховного процесу в навчальному закладі саме за рахунок координації знань у єдиній системі, яка здатна забезпечити підвищення результативності пізнавальної діяльності майбутніх фахівців, якості їх знань, доступності навчання, знаходить своє відображення в дослідженнях Г. Бібік, А. Касперського, В. Максимової, С. Рибак, В. Сергієнка, І. Ткаченко, Л. Шаповалова та інших. У працях цих науковців зазначається, що дидактичною умовою і засобом глибинного й всебічного засвоєння основ наук у навчальних закладах $\epsilon$ міжпредметні зв’язки, які є провідним поняттям для нашого дослідження.

У методичній літературі $є$ багато визначень поняття «міжпредметні зв’язки». Так, під М3 І. Звєрєв розуміє систему відношень між знаннями, уміннями та навичками, які формуються в результаті послідовного відображення в засобах, методах та змісті навчальних дисциплін тих об'єктивних зв'язків, що наявні у реальному світі [4]. Тобто, можемо відзначити, що, в широкому розумінні слова, міжпредметні зв'язки $є$ педагогічним еквівалентом дидактичних зв’язків, які реалізуються в навчальному процесі.

О. Сергєєв розглядав М3 з загальнопедагогічної позиції як один із методів комплексного підходу до навчання та виховання. Він указував на науково-практичне значення М3 з погляду цілісності процесу навчання [11]. Наведені думки дослідника дозволяють зробити висновок про те, що МЗ, відображаючи комплексний підхід до виховання і навчання, уможливлюють виокремлення як головних елементів змісту освіти, так і взаємозв'язків між навчальними предметами.

Більшість науковців трактують МЗ як складову частину принципу систематичності навчання. Так, Т. Ільїна обмежує зміст поняття «міжпредметні зв’язки» організаційним аспектам, ототожнює їх 3 поняттям засобу та виявленням їх у принципі систематичності [5].

У різний час поняття М3 трактувалося дослідниками як самостійний дидактичний принцип, як дидактична умова, педагогічна умова, як система роботи викладача та студента i т.д. Так, надаючи визначення поняття 
«міжпредметні зв'язки», Н. Антонов та Г. Бібік доходять до висновку про багатозначність їх статусного тлумачення: у якості визначника МЗ $\epsilon$ «дидактичний принцип», «засоби оптимізації», «умова» і так далі [1; 2].

Аналіз визначень МЗ, який знайшов своє відображення в педагогічній літературі, дає нам підстави для твердження, що міжпредметні зв'язки не належать до принципів навчання, вони входять як необхідний компонент до змісту дидактичних принципів науковості, системності, послідовності і доповненості і $є$ умовою для підвищення наукового рівня знань студентів та оптимізації процесу навчання. Причини багатозначного трактування поняття «міжпредметні зв'язки» бачимо в їх багатофункціональності та багатоаспектності.

У контексті дослідження, пов'язаного 3 методикою застосування міжпредметних зв'язків, особливого значення набуває впровадження міжпредметних зв'язків у навчальний процес підготовки майбутніх учителів. Узагальнюючи вищевикладене, використовуватимемо поняття «міжпредметні зв'язки» в такому контексті: міжпредметні зв'язки $\epsilon$ інтегрувальним елементом, що виявляється у змісті, формах, методах та засобах навчального процесу, який характеризується загальнодидактичними принципами науковості, систематичності, послідовності і доступності, зв 'язку теорії з практикою та спеціальними - приниип єдності різноманітного, доповненості та результативності. Тобто, в теоретичному аспекті міжпредметні зв'язки виявляються не тільки в принципі систематичності, але й у принципах науковості, наочності тощо. Це свідчить про те, що проблема МЗ, яка зумовлена предметною структурою навчання, має розглядатися комплексно.

Найважливішою умовою успішного здійснення процесу реалізації М3 у процесі підготовки майбутніх учителів є створення позитивної мотивації, відчуття важливості реалізації М3, установки на активну участь у процесі формування міжпредметних знань у майбутніх учителів. Мотивація навчальної діяльності складається із сукупності певних мотивів, а мотив, в свою чергу, - це предмет діяльності, за яким завжди стоїть певна потреба, як зазначається у працях науковців. У свою чергу, потреба викликає певне переживання, інтерес, надає смислу навчальній діяльності.

Висновки. Для того, щоб сформувати позитивне ставлення майбутніх учителів до реалізації міжпредметних зв'язків, необхідно застосовувати мотиваційні ситуації; учити студентів визначати близькі і перспективні завдання, формувати уміння їх реалізовувати; виховувати прагнення у студентів до пошуку засобів формування міжпредметних знань, умінь та навичок; використовувати новітні форми і засоби навчання.

Міжпредметні зв'язки становлять важливу передумову підвищення ефективності навчання, надають можливість сформувати та глибше засвоїти поняття на заняттях із різних дисциплін та $\epsilon$ першим етапом здійснення інтеграції, за якого викладач ставить за мету стимулювання внутрішніх сил особистості до саморозвитку, спонукання студентів до творчого пошуку.

Проблема міжпредметних зв'язків детально досліджена в дидактиці: визначено їх теоретичні засади, умови i форми реалізації в навчальній 
практиці та зміст діяльності викладача, спрямованої на підготовку та організацію навчання з урахуванням МЗ. Доробок науковців-дидактів був основою під час розроблення методики застосування МЗ курсів «Загальної фізики» та «Основи охорони праці» в процесі підготовки майбутніх учителів, яку буде викладено в подальших публікаціях.

\section{Література}

1. Антонов Н. С. Слагаемые знаний: о межпредметных связях в учебном процессе / Н. С. Антонов. - Архангельск : Сев-Зап. кн. изд-во, 1969. - 152 с.

2. Бібік Г. В. Міжпредметні зв'язки математики і фізики як засіб формування ключових компетентностей учнів основної школи : автореф. дис. на здобуття наук. ступеня канд. пед. наук : спец. 13.00 .02 «Теорія та методика навчання (математика)»/ Г. В. Бібік. - Херсон, 2010. - 20 с.

3. Гончаренко С. У. Зміст освіти і їі гуманітаризації / С. У. Гончаренко; за ред. І. Я. Зязюна. - К., 2000. - 161 с.

4. Зверев И. Д. Взаимная связь учебных предметов / И. Д. Зверев. - М. : Знание, 1977. $-126 \mathrm{c}$

5. Ильина Т. А. Педагогика / Т. А. Ильина. - М. : МГПИ, 1977. - 258 с.

6. Калягин Ю. М. Интеграция школьного обучения / Ю. М. Калягин, О. Л. Алексенко // Начальная школа. - 1990. - № 9. - С. 28-29.

7. Касперський А. В. Радіоелектроніка в системі формування фізичних і технічних знань у середніх загальноосвітніх та вищих педагогічних навчальних закладах: дис. ... докт. пед наук : 13.00.02 / Касперський Анатолій Володимирович. - К., 2003. - 524 с.

8. Козловська I. М. Теоретико-методологічні аспекти інтеграції знань учнів професійно-технічної школи: дидактичні основи / І. М. Козловська.- Львів, 1999. - 302 с.

Стаття надійшла до редакції 14.05.2012 p.

\section{ТЕХНОЛОГІЯ ФОРМУВАННЯ ВМІНЬ КОНСТРУКТИВНОЇ ВЗАЕМОДІЇ МАЙБУТНІХ МЕНЕДЖЕРІВ} менеджерів.

Гагіна Н. В. Технологія формування вмінь конструктивної взаємодї майбутніх

У статті подано технологію формування в майбутніх менеджерів умінь конструктивної взаємодії в ситуачії конфлікту, визначено ї̈ компоненти. Формування вмінь конструктивної взаємодї здійснюється відповідно до таких етапів: діагностувально-мотивачійного, теоретичного, тренувально-діяльнісного, рефлексивно-коригувального та творчого.

Ключові слова: педагогічна технологія, формування вмінь конструктивної взаємодії в ситуації конфлікту, майбутні менеджери.

Гагина Н. В. Технология формирования умений конструктивного взаимодействия будущих менеджеров.

В статье представлена технология формирования у будущих менеджеров умений конструктивного взаимодействия в ситуации конфликта, определень ее компоненты. Формирование умений конструктивного взаимодействия осуществляется в соответствии со следующими этапами: диагностико-мотивационного, теоретического, тренировочнодеятельностного, рефлексивно-корректирующего и творческого.

Ключевые слова: педагогическая технология, формирование умений конструктивного взаимодействия в ситуации конфликта, будущиие менеджеры. 